\title{
The Effectiveness of Immersive Multimedia Learning with Peer Support on English Speaking and Reading Aloud
}

\author{
Asnawi Muslem \\ English Education Study Program, Faculty of Teacher Training and Education, Syiah \\ Kuala University, Banda Aceh, Indonesia,nawi.muslem@gmail.com

\section{Merza Abbas} \\ Center for Instructional Technology and Multimedia, University of Science of Malaysia \\ Pulau Penang, Malaysia, merza@usm.my
}

\begin{abstract}
This study investigated the impacts of the immersive multimedia learning strategy with peer support on production skills in reading and speaking. Moreover, the effects of it on performance were investigated by student achievement. The quasiexperimental design with post-test was employed for the study. 80 first-year university students enrolled in English as a foreign language course were selected for this study. Data were analysed using one-way ANOVA. The findings showed that the immersive multimedia learning with peer support group reported significantly better performance in all measures of oral production for reading and speaking. Analyses obtained by achievement showed that the high achievement students in the immersive multimedia learning with peer support group reported significantly better performance in all measures of oral production only for speaking while the low achievement students in the immersive multimedia learning with peer supported group reported significantly better performance in all measures of oral production for reading and speaking. These findings showed that the immersive multimedia technique with peer support reduced the use of codeswitching strategies among the students and enabled them to develop oral production skills in English approaching the patterns of native speakers especially among low achievement students.
\end{abstract}

Key Words: immersive learning, peer support, speaking, reading aloud, learning

\section{INTRODUCTION}

Many university students in Indonesia encounter difficulties in learning and communicating through English language automatically and effectively particularly in relation to critical thinking when they continue their studies abroad. The processes of teaching and learning English at university level in Indonesia have used various methods to achieve the goals. However, students have still difficulties in communicating in 
English orally. According to Kweldju (2002) many students who received high English scores at senior high school levels and university are still experiencing difficulty in speaking, pronouncing, and reading English words correctly. This problem is endemic and covers English and non-English majors (Kweldju, 2002). The ways and methods to improve such situation are urgently needed. Therefore, this study offers an alternative teaching and learning English method through immersive multimedia learning with peer support to improve students' oral production skills in reading and speaking.

One of the appropriate methods to apply in the teaching and learning process to improve students' language skills is immersion program (Tallinn, 2005). Following Levelt (1989) as simplified by de Bot (1997), to acquire a language better, learners need a program that develops the language lexicon and semantic structure efficiently. Gibbons (2002) suggests the use of an immersive and linguistically and culturally rich environment, and employ a range of learning strategies to bring the process of meaningful learning on the language skills. The application of the appropriate methods or approaches and strategies play important roles to master a second language. For example, if someone wants to learn and master English language quickly, he or she should stay in the country where English language is used (Wilkinson, 2006).

Advances in ICT and multimedia now allow for linguistically rich learning environments to be created by compiling recorded contents to provide the immersive inputs in place of the teacher (Salaberry, 2001; Coiro, Knobel, Lankshear, \& Leu, 2008; Chapelle, 2003; Larsen-Freeman \& Freeman, 2008). Multimedia packages for immersive learning are the tools students use to construct language skills, knowledge, and understand their world. English language acquisition is integrated in the learning of all subject areas. This goal can be achieved by providing a linguistically rich learning environment through an alternative means: English books, videos, CDs, you tube, radio and TV programs, posters, visuals, Web sites, songs, and dramatizations. All play a central role in second language learning (Alberta Education, 2010). The frequent use of authentic multimedia situation enables students to make links between what they are learning in school in English and real life situation (Alberta Education, 2010; Met, 1987). Students need to be exposed to a rich environment and be provided with various learning strategies that will support their learning adventure that is very new to them (Kagan, 1995; Gibbons, 2002). The presence of peer support or social interaction in the learning English as a foreign or second language is important (Kagan, 1995).

This study is based on Levelt's (1989) lexicon model of language acquisition and production. The model explains the acquisition of a language through the development of internal structures in the form of speech motor patterns, conceptual systems, articulatory motor systems and phonemization, which takes the approach that language is a reconstruction or reproduction from learned phonological codes. Levelt presents the process of improving language skill by using the lexicon model (Levelt, 1989).

\section{Immersive strategies}

Immersion is a form of experiential learning where the learning processes involve deep engagement and absorption with the target language through all the senses. Immersion programs have been implemented in many countries such as United State, Canada, 
Spain, New Zealand, etc., with the purpose of improving students' second language acquisition and learning (Tallin, 2005; Cummins, 2000). Immersion is a relatively new development within bilingual education, but it is an option (and a term) that is being adopted more and more widely. Immersion programs aim to provide the quantity and quality of involvement in the use of target language that ensure the development of a high level of proficiency (Johnson \& Swain, 1997).

Language immersion is a method of teaching a second language (L2) in which the target language is used as both curriculum content and media of instruction (Pacific Policy Research Center, 2010). The need to have an immersion program for L2 or foreign language as a result of students' achievement is not significantly satisfied. Many students have studied English at school, but their ability to use the target language is still far from the expectation. The focus of teaching and learning process nowadays is on grammar, memorization, and drill, which have not provided students with sufficient skill to work in English or to socialize with English speakers (Johnson \& Swain, 1997; Cummins, 1998; Tallin, 2005). They may have some or no exposure to the L2 outside the school. Immersion programs were first instituted in Montreal, Canada, in 1965.

The English immersion can be done by integrating of the target language and content area instructions. Learners learn English language about the English language through the target language (Tallinn, 2005; Alberta Education, 2010). The aim of learning the language is to enable learners to read, speak, write and listen in English. Learning about the target language is that learners study English as a subject. Learners learn through language is that they use English to solve problems, understand concepts and create new knowledge (Alberta Education, 2010). These three notions are interwoven throughout the students' English immersion experience. They learn the language as they are acquiring concepts in different subjects. As learners learn to read, they also read to learn (Alberta Education, 2010). Learners learn a second language to enable them to use the target language in meaningful context. In English immersion, learners are given opportunities to use for a variety of purposes. In the end, learning through language entails that all English lesson multimedia immersive strategies are also strategies of language. Students meet their outcomes identified for various lessons (Tallin, 2005; Alberta Education, 2010).

\section{Immersive multimedia learning}

The immersive multimedia method in this study uses multimedia immersion program. It means that the target language (English) is as the main instruction in the process of teaching and learning activities (Lenker \& Rhodes, 2007). The program is designed for first year university students. This method of teaching and learning English or any language in this world has been used for more than thirty five years (Cummins, 2000; Lenker \& Rhodes, 2007). During the time, the teacher plays an important role in the teaching and learning process. Teacher is as a model of presenting teaching and learning materials in the classroom (Cummins, 2000; Tallin, 2005; Lenker \& Rhodes, 2007; Alberta Education, 2010). However, in the current study, the role of teacher is limited. Teacher is a facilitator or an organizer in the classroom. The students do activities either in the classroom or outside the classroom to immerse themselves by listening and 
watching video clips and recordings provided by the teacher. The students may learn with or to master the contents of the learning materials.

The multimedia supported in the form of video clips and recoding materials would be as the fundamental input. Students may repeat the playback several times to absorb each learning material from the clips and recordings until they master them naturally so that they can reproduce the language as accurately accordingly to the native speakers.

\section{Peer Support and Language Learning environment}

Linguists and language researchers have conducted studies that related to the implementation of Peer Support strategies in language learning (Angelova, Gunawardena, \& Volk, 2006; De Guerrero \& Villamil, 2000; Emerson, Rees, \& Mackay, 2005; Ertmer et al., 2007; Li, 2009). Li (2009) conducted a study on peer interaction in an EFL classroom in Hong Kong to improve students' performance. The study found that by student-student interaction the learners jointly construct a scaffold that allows them to successfully complete the activity and co-construct their own system of making meaning through words in a second language.

In addition, support in peer support may confine the development of ZPD, there appears to be a necessary role for an expert (e.g., the teacher) or a more capable peer who can manage the interaction well, model appropriate forms and monitor the learners' production in a proper way. As peer mediation is not always effective, expert mediation is required on occasions when peers find it difficult to push their ZPD. Meanwhile, social interaction can contribute to language learning and the extension of ZPD only when there are opportunities for students to offer assistance or digest prompts, under meticulous, proper use of scaffolding strategies and appropriate feedback from the teacher or peers $(\mathrm{Li}, 2009)$. This study focused on speaking to negotiate meaning and form with peer interaction. The results obtained from many studies conducted by language researchers indicate that the use of multimedia immersive learning improves students' language skills in terms of reading and speaking (Kuo (2009; Echandy, 2011; BavaHarji, 2014; Kabilan et al., 2010; AbuSeileek, 2007; Shih, 2010; Wu, 2013; Diyyab, 2013; Kessler, 2010; Murat, 2012).

However, few studies have been conducted in terms of improving oral production skills through peer-supported multimedia strategy among low and high achievers. Grgurovic (2007) conducted a research in terms of using multimedia with subtitle and peer interaction to improve language oral production skills among high and low achievers. The study found that the use of subtitles and transcripts through multimedia supported improved the achievement among high achievers than low achievers. The finding also reported that the higher proficiency group used subtitles more frequently and for longer amounts of time than the lower proficiency group although both groups exhibited very similar behaviour on transcripts. Another study conducted by Pujola (2002) and Aslan (2009), who investigated the use of multimedia lesson with subtitles to improve language skills among high and low achievers, found that participants in each group had different ways of learning the language. It was difficult to draw conclusions that would be applied to all participants in one group especially since some participants in the lower group never used textual help. The study also reported that generally the high achievers used the replay and rewind functions more than the transcripts and or subtitles. 


\section{Research Aim}

The purpose of the study was to investigate the effects of the immersive multimedia learning technique with peer support. Specifically, this study has the following objectives:

i. To investigate whether there are significant differences in terms of oral production in (a) reading and (b) speaking between the students who received immersive multimedia learning with peer support and those who did not receive such support.

ii. To identify whether there are significant differences in terms of oral production in (a) reading and (b) speaking among high achievement students who received immersive multimedia learning with peer support and those who did not receive such support.

iii. To identify whether there are significant differences in terms of oral production in (a) reading and (b) speaking among low achievement students who received immersive multimedia learning with peer support and those who did not receive such support.

\section{METHOD}

The quasi-experimental design with post-test was employed for this study. The design was employed to investigate the effectiveness of the immersive multimedia learning with peer support on English speaking and reading aloud. Intact classes were used for this study to retain the actual learning environment and for easy manipulation and control of the research variables. The independent variable was the immersive multimedia learning strategy with peer support activities and without peer support activities. Both groups have quite similar characteristics. ANOVA analysis was used to determine the difference between the respondents of the two groups.

The data obtained from post-tests were analyzed by using descriptive and inferential statistical methods involving one-way ANOVA. The results of post-test were analyzed based on the assessment rubric for pausing, phrasing, stress, intonation, rate, and integration that was developed to assess students' oral production. The minimum score the rubric is one (1) and ten (10). The students' performance in the oral production tests was recorded to ensure the correctness and the validity of the collected data. To verify the data, inter-rater reliability was used.

\section{Study Samples}

The samples of the study were 80 first year of English department students studying at Syiah Kuala University, Banda Aceh, Indonesia. All the students were under 18-20 years of age. All the population would be the sample of the study from four existing classes at Syiah Kuala University English department, Banda Aceh. Intact classes were used and both classes used the immersion program. From the sample, 40 students were assigned as immersive learning with peer support (high \& low achievers) and 40 students assigned as immersive learning without peer support (high \& low achievers). One class employed peer support activities with pair group formed based on students' choice of partners. The other group worked without peer. The researchers checked for equivalence in English achievement in Indonesian National Examination by class. The results found that there were no significant differences between the classes. 
The research instruments of this study consisted of test (post-test). At the end of the treatment, post-test was conducted to investigate if the treatment using immersive multimedia learning with peer support and without peer support improved students' performances. The post-test covered oral production in reading and speaking for pausing, phrasing, stress, intonation, rate, and integration aspects. Oral production (fluency test of reading and speaking) abilities were tested orally and recorded in order to offer the researcher better reference to analyse the data. The oral production skills in post-test for reading and speaking were based on the topics being learned by both groups. The post-test for speaking was conducted by interviewing students one by one. There were 10 questions in the interview and all were taken from the topics being learned from the video lessons. The questions are: (1) How are you? (2) Can you introduce yourself please? (3) Do you have any hobbies? (4) Can you introduce your friend to me? (5) Learning English from native speaker is quite interesting, what do you think about this statement? (6) Do you like speaking class? Why? (7) How would you improve your speaking? (8) I would like to go to Zainal Abidin General Hospital, could you tell me how to get there from here? (9) Tell me about your learning English experience you have during the first semester of your study? And (10) What do you like to do in your free time? Each question was measured by using rubric mentioned. The lowest score was one (1) and the highest score was ten (10) for each question. So the minimum score was 10 and the maximum was 100.

\section{FINDINGS}

Table 1 reports the means, standard deviations, and results of ANOVA for oral production in reading by treatment. Students in the peer-support group reported higher mean scores for all dimensions of oral production and results of the ANOVA tests reported significant differences, i.e., that $\mathrm{p}<.05$ for all the aspects. Thus, the findings indicate that the peer support strategy significantly improved oral production in reading for pausing, phrasing, stress, intonation, rate, and integration.

Table 1

Means, Standard Deviations, and results of ANOVA for Oral Production in Reading by Treatment

\begin{tabular}{|c|c|c|c|c|c|}
\hline Aspects & Groups & $N$ & Mean & Std. Deviation & $A N O V A$ \\
\hline \multirow[t]{2}{*}{ Pausing } & With peer support & 40 & 7.15 & .69 & \multirow{2}{*}{$\begin{array}{l}F(1,78)=6.382 \\
p=.014\end{array}$} \\
\hline & W/O peer support & 40 & 6.70 & .88 & \\
\hline \multirow[t]{2}{*}{ Phrasing } & With peer support & 40 & 6.95 & .87 & \multirow{2}{*}{$\begin{array}{l}F(1,78)=9.889 \\
p=.002\end{array}$} \\
\hline & W/O peer support & 40 & 6.27 & 1.03 & \\
\hline \multirow[t]{2}{*}{ Stress } & With peer support & 40 & 6.85 & .89 & \multirow{2}{*}{$\begin{array}{l}F(1,78)=14.224 \\
p=.000\end{array}$} \\
\hline & W/O peer support & 40 & 6.07 & .94 & \\
\hline \multirow[t]{2}{*}{ Intonation } & With peer support & 40 & 7.72 & .75 & \multirow{2}{*}{$\begin{array}{l}F(1,78)=18.676 \\
p=.000\end{array}$} \\
\hline & W/O peer support & 40 & 6.87 & .99 & \\
\hline \multirow[t]{2}{*}{ Rate } & With peer support & 40 & 7.07 & .69 & \multirow{2}{*}{$\begin{array}{l}F(1,78)=12.519 \\
p=.001\end{array}$} \\
\hline & $\mathrm{W} / \mathrm{O}$ peer support & 40 & 6.45 & .87 & \\
\hline \multirow[t]{2}{*}{ Integration } & With peer support & 40 & 7.67 & .82 & \multirow{2}{*}{$\begin{array}{l}F(1,78)=17.022 \\
p=.000\end{array}$} \\
\hline & W/O peer support & 40 & 6.92 & .79 & \\
\hline
\end{tabular}

Table 2 reports the means, standard deviations, and results of ANOVA for oral production in speaking by treatment. Students in the peer-supported group reported 
higher mean scores for all dimensions of oral production and the results of ANOVA tests reported significant differences, i.e., that $p<.05$ for all the aspects. Thus, the findings indicate that the peer-supported strategy significantly improved oral production in speaking for pausing, phrasing, stress, intonation, rate, and integration.

Table 2

Means, Standard Deviations, and results of ANOVA for Oral Production in Speaking by Treatment

\begin{tabular}{llllll}
\hline Aspects & Groups & N & Mean & Std. Deviation & ANOVA \\
\hline Pausing & With peer support & 40 & 6.75 & .77 & $\mathrm{~F}(1,78)=11.919$ \\
& W/O peer support & 40 & 6.17 & .71 & $\mathrm{p}=.001$ \\
\hline \multirow{2}{*}{ Phrasing } & With peer support & 40 & 6.37 & .70 & $\mathrm{~F}(1,78)=44.892$ \\
& W/O peer support & 40 & 5.37 & .62 & $\mathrm{p}=.00$ \\
\hline \multirow{2}{*}{ Stress } & With peer support & 40 & 5.95 & .87 & $\mathrm{~F}(1,78)=21.774$ \\
& W/O peer support & 40 & 5.20 & .51 & $\mathrm{p}=.000$ \\
\hline \multirow{2}{*}{ Intonation } & With peer support & 40 & 6.65 & .80 & $\mathrm{~F}(1,78)=29.885$ \\
& W/O peer support & 40 & 5.65 & .83 & $\mathrm{p}=.000$ \\
\hline \multirow{2}{*}{ Rate } & With peer support & 40 & 6.80 & .68 & $\mathrm{~F}(1,78)=47.561$ \\
& W/O peer support & 40 & 5.80 & .60 & $\mathrm{p}=.000$ \\
\hline Integration & With peer support & 40 & 7.22 & .65 & $\mathrm{~F}(1,78)=16.571$ \\
& W/O peer support & 40 & 6.17 & & $\mathrm{p}=.000$ \\
\hline
\end{tabular}

Table 3 reports the means, standard deviations, and results of ANOVA for oral production in reading by treatment and high English achievement. High achievement students in the peer-supported group reported similar mean scores for all dimensions of oral production in reading and the results of ANOVA tests reported no significant differences, i.e., that $\mathrm{p}>.05$ for all the aspects. Thus, these findings indicated that the peer-supported strategy did not significantly improve oral production in reading for pausing, phrasing, stress, intonation, rate, and integration among high English achievers.

Table 3

Means, Standard Deviations, and results of ANOVA for Oral Production in Reading by Treatment and high English achievement

\begin{tabular}{llllll}
\hline \multirow{2}{*}{ Aspects } & Groups & $N$ & Mean & Std. Deviation & ANOVA \\
\hline Pausing & With peer support & 12 & 7.00 & .85 & $\mathrm{~F}(1,24)=.057$ \\
& W/O peer support & 13 & 6.92 & .75 & $\mathrm{p}=.814$ \\
\hline \multirow{2}{*}{ Phrasing } & With peer support & 12 & 6.83 & .83 & $\mathrm{~F}(1,24)=.127$ \\
& W/O peer support & 13 & 6.69 & 1.10 & $\mathrm{p}=.725$ \\
\hline \multirow{2}{*}{ Stress } & With peer support & 12 & 6.58 & .79 & $\mathrm{~F}(1,24)=.768$ \\
& W/O peer support & 13 & 6.23 & 1.16 & $\mathrm{p}=.390$ \\
\hline \multirow{2}{*}{ Intonation } & With peer support & 12 & 7.33 & .65 & $\mathrm{~F}(1,24)=.283$ \\
& W/O peer support & 13 & 7.15 & .98 & $\mathrm{p}=.600$ \\
\hline \multirow{2}{*}{ Rate } & With peer support & 12 & 7.00 & .60 & $\mathrm{~F}(1,24)=1.917$ \\
\cline { 2 - 6 } & W/O peer support & 13 & 6.61 & .76 & $\mathrm{p}=.180$ \\
\hline \multirow{2}{*}{ Integration } & With peer support & 12 & 7.50 & .90 & $\mathrm{~F}(1,24)=.601$ \\
\cline { 2 - 6 } & W/O peer support & 13 & 7.23 & .83 & $\mathrm{p}=.446$ \\
\hline
\end{tabular}


Table 4 reports the means, standard deviations, and results of ANOVA for oral production in speaking by treatment and high English achievement. High achievement students in the peer-support group reported consistently higher mean scores for all dimensions of oral production in reading and the results of ANOVA tests reported significant differences, i.e., that $\mathrm{p}<.05$ for all the aspects. Thus, hypothesis is accepted. These findings indicate that the peer-support strategy significantly improved oral production in speaking for pausing, phrasing, stress, intonation, rate, and integration among high English achievers.

Table 4

Means, Standard Deviations, and results of ANOVA for Oral Production in Speaking by Treatment and High English Achievement

\begin{tabular}{llllll}
\hline \multicolumn{7}{c}{ High English Achievement } \\
\hline \multirow{2}{*}{ Pauspects } & Groups & $N$ & Mean & Std. Deviation & ANOVA \\
& With peer support & 12 & 6.91 & .79 & $\mathrm{~F}(1,24)=8.945$ \\
& W/O peer support & 13 & 5.92 & .86 & $\mathrm{p}=.007$ \\
\hline \multirow{2}{*}{ Phrasing } & With peer support & 12 & 6.50 & .67 & $\mathrm{~F}(1,24)=26.261$ \\
& W/O peer support & 13 & 5.30 & .48 & $\mathrm{p}=.000$ \\
\hline \multirow{2}{*}{ Intress } & With peer support & 12 & 6.16 & .83 & $\mathrm{~F}(1,24)=12.961$ \\
& W/O peer support & 13 & 5.15 & .55 & $\mathrm{p}=.002$ \\
\hline \multirow{2}{*}{ Rate } & With peer support & 12 & 6.75 & .75 & $\mathrm{~F}(1,24)=17.674$ \\
& W/O peer support & 13 & 5.46 & .77 & $\mathrm{p}=.000$ \\
\hline \multirow{nyyyyyy}{*}{ Integration } & With peer support & 12 & 6.75 & .62 & $\mathrm{~F}(1,24)=28.161$ \\
& W/O peer support & 13 & 5.53 & .51 & $\mathrm{p}=.000$ \\
\cline { 2 - 6 } & With peer support & 12 & 7.16 & .57 & $\mathrm{~F}(1,24)=19.842$ \\
\cline { 2 - 6 } & W/O peer support & 13 & 6.07 & .64 & $\mathrm{p}=.000$ \\
\hline
\end{tabular}

Table 5 reports the means, standard deviations, and results of ANOVA for oral production in reading by treatment and low English achievement. Low achievement students in the peer-supported group reported consistently higher mean scores for all dimensions of oral production in reading and the results of ANOVA tests reported significant differences, i.e., that $\mathrm{p}<.05$ for all the aspects. Thus, hypothesis is accepted. These findings indicated that the peer-support strategy significantly improved oral production in reading for pausing, phrasing, stress, intonation, rate, and integration among low English achievers.

Table 5

Means, Standard Deviations, and results of ANOVA for Oral Production in Reading by Treatment and Low English achievement

\begin{tabular}{llllll}
\hline \multicolumn{2}{l}{ Low English Achievement } & & & & \\
\hline Aspects & Groups & $N$ & Mean & Std. Deviation & ANOVA \\
\hline Pausing & With peer support & 28 & 7.21 & .62 & $\mathrm{~F}(1,54)=8.473$ \\
& W/O peer support & 27 & 6.59 & .93 & $\mathrm{p}=.005$ \\
\hline \multirow{2}{*}{ Phrasing } & With peer support & 28 & 7.00 & .90 & $\mathrm{~F}(1,54)=13.622$ \\
& W/O peer support & 27 & 6.07 & .95 & $\mathrm{p}=.001$ \\
\hline \multirow{2}{*}{ Stress } & With peer support & 28 & 6.96 & .92 & $\mathrm{~F}(1,54)=16.536$ \\
& W/O peer support & 27 & 6.00 & .83 & $\mathrm{p}=.000$ \\
\hline
\end{tabular}




\begin{tabular}{llllll}
\hline Intonation & With peer support & 28 & 7.89 & .73 & $\mathrm{~F}(1,54)=24.258$ \\
\cline { 2 - 6 } & W/O peer support & 27 & 6.74 & .98 & $\mathrm{p}=.000$ \\
\hline \multirow{2}{*}{ Rate } & With peer support & 28 & 7.10 & .73 & $\mathrm{~F}(1,54)=10.695$ \\
& W/O peer support & 27 & 6.37 & .92 & $\mathrm{p}=.002$ \\
\hline Integration & With peer support & 28 & 7.75 & .79 & $\mathrm{~F}(1,54)=21.575$ \\
& W/O peer support & 27 & 6.77 & .75 & $\mathrm{p}=.000$ \\
\hline
\end{tabular}

Table 6 reports the means, standard deviations, and results of ANOVA for oral production in speaking by treatment and low English achievement. Low achievement students in the peer-supported group reported consistently higher mean scores for all dimensions of oral production in reading and the results of ANOVA tests reported significant differences, i.e., that $\mathrm{p}<.05$ for all the aspects. Thus, hypothesis is accepted. These findings indicate that, the peer-supported strategy significantly improved oral production in speaking for pausing, phrasing, stress, intonation, rate, and integration among low English achievers.

Table 6

Means, Standard Deviations, and results of ANOVA for Oral Production in Speaking by Treatment and Low English Achievement

\begin{tabular}{llllll}
\hline \multicolumn{2}{l}{ Low English Achievement } & & & \\
\hline Aspects & Groups & $N$ & Mean & Std. Deviation & ANOVA \\
\hline Pausing & With peer support & 28 & 6.67 & .77 & $\mathrm{~F}(1,54)=4.136$ \\
& W/O peer support & 27 & 6.29 & .60 & $\mathrm{p}=.047$ \\
\hline \multirow{2}{*}{ Phrasing } & With peer support & 28 & 6.32 & .72 & $\mathrm{~F}(1,54)=22.858$ \\
& W/O peer support & 27 & 5.40 & .69 & $\mathrm{p}=.000$ \\
\hline \multirow{2}{*}{ Stress } & With peer support & 28 & 5.85 & .89 & $\mathrm{~F}(1,54)=10.453$ \\
& W/O peer support & 27 & 5.22 & .50 & $\mathrm{p}=.002$ \\
\hline Intonation & With peer support & 28 & 6.60 & .83 & $\mathrm{~F}(1,54)=14.443$ \\
& W/O peer support & 27 & 5.74 & .85 & $\mathrm{p}=.000$ \\
\hline \multirow{2}{*}{ Rate } & With peer support & 28 & 6.82 & .72 & $\mathrm{~F}(1,54)=24.384$ \\
& W/O peer support & 27 & 5.92 & .61 & $\mathrm{p}=.000$ \\
\hline Integration & With peer support & 28 & 7.25 & .70 & $\mathrm{~F}(1,54)=29.693$ \\
& W/O peer support & 27 & 6.22 & .69 & $\mathrm{p}=.000$ \\
\hline
\end{tabular}

\section{DISCUSSION}

Analyses of the data obtained by treatment methods found that the immersive multimedia learning technique with peer support significantly improved oral production in reading and speaking for pausing, phrasing, stress, intonation, rate, and integration. This finding consisted with BavaHarji, 2014; Kabilan et al., 2010; AbuSeileek, 2007; Shih, 2010; Diyyab, 2013; Kessler, 2010; Murat, 2012). The group with peer support group reported greater success on the learning outcomes compared to the individual group because of the immediate feedbacks and corrections or additional coaching from their partners to refine their mastery of the language. Students in the individual group did not improve oral production skills for reading and speaking during learning activities because they did not receive immediate feedback and corrections or additional coaching to refine their mastery of the language. 
Analyses obtained by English achievement and treatment methods found that the peer support strategy significantly improved oral production in reading for pausing, phrasing, stress, intonation, rate, and integration among low English achievers but not high achievers. Also, the peer support strategy significantly improved oral production in speaking for pausing, phrasing, stress, intonation, rate, and integration among high and low English achievers. The study found that the peer support strategy significantly improved oral production in reading for pausing, phrasing, stress, intonation, rate, and integration among low English achievers but not high achievers. Many studies have been conducted to investigate the improvement of oral production skills through peer supported multimedia strategies (Pujola, 2002; Aslan, 2009; Kabilan et al., 2010; Shih, 2010; Kessler, 2010; Murat, 2012; Wu, 2013; Diyyab, 2013; BavaHarji, 2014), however, few studies have reported their effects among low and high achievers. The finding of this study contradicts a previous study by Grgurovic (2007) who conducted a research in terms of using multimedia with subtitle and peer interaction to improve language oral production skills among high and low achievers. The immersive peer supported multimedia package was very beneficial for low ability students as indicated by significant improvements on both speaking and reading oral production. It is also useful for high ability students for improving their speaking skills but this finding must be taken with caution as the sample size for high ability students was not large enough for robust statistical inferences to be made.

\section{Implication and Contribution of the study}

This study has contributed an alternative and effective way to improve students' performance in English oral production skills for reading and speaking through the use of immersive multimedia learning with peer support. The benefits appeared to be received by low achievers to improve their English oral skills following native speakers' levels. Also, it enables students to communicate in the target language automatically without mediation through their native language. The most important element in this study was that the lessons enabled non-native English learners to acquire native-speaker oral patterns without having to go abroad. Thus the contribution to theory is that this study showed that an L2 could be taught following L1 theory and this method that minimized the use of code switching strategies, and the contributions to practice are that any instructor can compile similar native speaker video lessons in any language and use them without much hassle.

\section{Limitation and Recommended Future Studies}

This study is limited to the use of limited peer support activities and learning strategies. The study involved high achievers in small sample sizes. As such these findings, especially regarding the high achievers might not be fully generalizable. Based on the results of the study, some recommendations are made for the following people and educational institution. Teachers and lecturers should use this strategy to develop oral skills in the process of teaching and learning English as a foreign language or second language. They are also suggested to find more teaching material clips that relate to students' varied interest and needs so that the process of teaching and learning become interesting and contextual. Students are suggested to use this strategy in the process of 
learning English as a foreign or second language. Students are also suggested to practice using English every time either with partners or lecturers in the class or outside the classroom to make a better performance in terms of oral production skills for reading and speaking. Knowing that immersive multimedia learning strategy with peer support has a great number of advantages, it is suggested that educational institutions should provide the required facilities such as tablets and headphones in schools and universities. In addition, the institution should also train lecturers/teachers to use technology in the process of teaching and learning the L2 based on L1 theories. Further studies are recommended to clarify the real outcomes for high ability students.

\section{CONCLUSION}

This study investigated the effects of multimedia supported immersive learning with and without peer-support to improve students' performances in term of oral production skills for reading and speaking. The findings showed that the immersive multimedia learning with peer support group reported significantly better performance in all measures of oral production for reading and speaking. Analyses obtained by achievement showed that the high achievement students in the immersive multimedia learning with peer support group reported significantly better performance in all measures of oral production only for speaking while the low achievement students in the immersive multimedia learning with peer supported group reported significantly better performance in all measures of oral production for reading and speaking.

These findings showed that the immersive multimedia technique with peer support that employed the L1 theory reduced the use of code-switching strategies among the students and enabled them to develop oral production skills in English approaching the patterns of native speakers especially among low achievement and female students.

\section{REFERENCES}

AbuSeileek, A. F. (2007). Cooperative vs. individual learning of oral skills in a CALL environment. Computer Assisted Language Learning, 20(5), 493-514.

Alberta Education. (2010) French Language Education Services; Handbook for French Immersion Administrator.

Angelova, M., Gunawardena, D., \& Volk, D. (2006). Peer teaching and learning: Coconstructing language in a dual language first grade. Language and education, 20 (3), 173-190

Aslan, O. (2009). The role of gender and language learning strategies in learning English. Master thesis. Middle East Technological University

BavaHarji, M., Gheitanchian, M., \& Letchumanan, K. (2014). The effects of multimedia task-based language teaching on EFL learners' oral L2 production. English Language Teaching, 7(4), p11.

Chapelle, C. (2003). English language learning and technology: Lectures on applied linguistics in the age of information and communication technology, John Benjamins. 
Coiro, J., Knobel, M., Lankshear, C. \& Leu, J. D. (Eds.). (2008). Handbook of research on new literacies. New York: Lawrence Erlbaum Associates, Taylor \& Francis Group.

Cummins, J. (1998). Immersion education for the millennium: What have we learned from 30 years of research on second language immersion? In M. R. Childs \& R. M. Bostwick (Eds.) Learning through two languages: Research and practice. Second Katoh Gakuen International Symposium on Immersion and Bilingual Education. (pp. 34-47). Katoh Gakuen, Japan.

Cummins, J. (2000). Immersion education for the millennium: What we have learned from 30 years of research on second language immersion. Retrieved October, 5, 2000.

De Bot, K., Paribakht, T. S., \& Wesche, M. B. (1997). Toward a lexical processing model for the study of second language vocabulary acquisition. Studies in second language acquisition, 19(03), 309-329.

De Guerrero, M., \& Villamil, O.S. (2000). Activating the ZPD: Mutual scaffolding in L2 peer revision. The Modern Language Journal, 84 (1), 51-68.

Diyyab, E.A., Abdel-Haq, E.M., \& Aly, M.A.S. (2013). Using Multimedia-Based Programm for Developing Students Teachers' EFL Speaking Fluency Skills. Online Submission.

Echandy, N.C. (2011). The media and lexical borrowing: Implication for vocabulary acquisition among ESL students. A Dissertation, Doctor of Philosophy, Department of Graduate Studies, College of Education, University of Puetro Rico. ProQuest LLC.

Emerson, L., Rees, M., \& Mackay, B. (2005). Scaffolding academic integrity: Creating a learning context for teaching referencing skills. Journal of University Teaching \& Learning Practice, 2 (3), 3

Ertmer, P. A., Richardson, J.C., Belland, B., Camin, D., Connolly, P., Coulthard, G., Mong, C. (2007). Using peer feedback to enhance the quality of student online postings: An explaratory study. Journal of Computer-Mediated Communication, 12 (2), 412-433. 216.

Gibbons, P. (2002). Scaffolding language, scaffolding learning: Portsmouth, NH: Heinemann.

Grgurovic, M., \& Hegelheimer, V. (2007). Help options and multimedia listening: Students " use of subtitles and the transcript. Language Learning \& tehnology, 11 (1), 45-66.

Gumperz, J. J. (1982). Conversational code-switching. In J. J. Gumperz (ed.) Discourse strategies. Cambridge: Cambridge University Press.

Johnson, R. K., \& Swain, M. (1997). Immersion education: International perspectives: Cambridge University Press.

Kabilan, M. K., Ahmad, N., \& Abidin, M. J. Z. (2010). Facebook: An online environment for learning of English in institutions of higher education? The Internet and Higher Education, 13(4), 179-187. 
Kagan, S. (1995). We can talk: Cooperative learning in the elementary ESL classroom (ERIC Digest). Washington, DC: ERIC Clearinghouse on Languages and Linguistics. 221.

Kessler, G. (2010). Fluency and anxiety in self-access speaking tasks: the influence of environment. Computer Assisted Language Learning, 23 (4), 361-375

Kuo, L. L (2009). The effects of youtube listening/viewing activities on Taiwanese EFL learners' lsitening comprehension. A Dissertation, Doctor of Philosophy Presented to the Faculty of School of Education, La Sierra University, ProQuest LLC

Kweldju, S. (2002). Pengajaran bahasa Inggris berbasis leksikon: Sebuah alternatif yang tepat untuk pengajaran bahasa Inggris di Indonesia. Pidato Pengukuhan Profesor dalam Bidang Kosakata. Fakultas Sastra, Universitas Negeri Malang, Indonesia, 3 Oktober 2002.

Larsen-Freeman, D. \& Freeman, D. (2008). Language moves: The place of "foreign" languages in classroom teaching and learning. Review of Research in Education, 32(1), 147-186.

Lenker, A., \& Rhodes, N. (2007). Foreign language immersion program: Features and trends over 35 years/ The ACIE Newsletter, 10 (2), 1-8

Levelt, W. J. M. (1989) Speaking: from intention to articulation. Cambridge, Massachusetts: The MIT Press.

Li, D. (2009). Is there a role for tutor in group work: Peer interaction in a Hong Kong EFL classroom. HKBU Paper in Applied Language Studies, Vol. 13, 12-40.

Met, M. (1987). Twenty questions: The most commonly asked questions about starting an immersion program. Foreign Language Annals, 20(4), 311-315.

Murat, H. (2012). Teaching word stress to Turkish EFL English as foreign language learners through internet-based video lessons. Retrieved from ERIC database. (ED 530678).

Pacific Policy Research Center. (2010). Successful bilingual and immersion education models/programs. Honolulu: Kamehameha Schools, Research \& Evaluation Division.

Pujola, J. T. (2002). Calling for help: Researching language learning strategies using help facilities in a web-based multimedia program. ReCALL, 14 (2), 235-262.

Salaberry, M. R. (2001). The use of technology for second language learning and teaching: A retrospective. The Modern Language Journal 85(1): 39-56.

Shih, R.-C. (2010). Blended learning using video-based blogs: Public speaking for English as a second language students. Australasian Journal of Educational technology, 26 (6), 883-897

Tallinn. (2005). An introduction to immersion handbook. in Talliin (Ed). Immersion Handbook (pp.3-4).

Wilkinson, G. S., \& Robertson, G. (2006). Wide range achievement test (WRAT4). Psychological Assessment Resources, Lutz. 
Wu, L., \& McMahon, M. (2013). Adopting a musical intelligence and e-learning approach to improve the English language pronunciation of Chinese students. AI \& SOCIETY, 1-10. 234.Strangman, N., \& Hall, T. (2003). Virtual reality/simulations.

\section{Turkish Abstract \\ Akran Destekli İngilizce Konuşma ve Yüksek Sesle Okumada Sarmal MultiMedya Öğreniminin Etkileri}

$\mathrm{Bu}$ çalışma okuma ve konuşmada akran destekli sarmal multimedya öğrenme stratejilerinin etkilerini araştırmaktadır. Ayrıca öğrenci kazanımlarının performanstaki etkileri de bu araştırmada incelenmiştir. Bu çalışma için son testli yarı deneysel desen tercih edilmiştir. Bu çalışma için Yabancı bir dil kursu olarak İngilizce Kursuna kayıtlı 80 üniversite birinci sınıf öğrencisi seçilmiştir. Veriler one-way ANOVA ile analiz edilmiştir. Bulgular okuma ve konuşmanın bütün ölçümlerinde akran destekli sarmal multmedya öğrenimi performanslarının tüm gruplarda anlamlı derecede iyi olduğunu göstermiştir. Kazanım analizleri akran destekli sarmal multimedya öğreniminde düşük akademik başarıya sahip öğrencilerin okuma ve konuşmada anlamlı derecede iyi performans gösterdiğini; yüksek akademik başarıya sahip öğrenci grubunun sadece konuşmada anlamlı derecede iyi performans gösterdiğini belirlemiştir. Bulgular sarmal multimedya öğreniminin öğrenciler arasında dil değişim stratejileri kullanımını azalttığını ve onlara özellikle düşük akademik başarıya sahip öğrenciler arasında İngilizceyi anadili gibi konuşma yeteneğini geliştirdiğini göstermiştir.

Anahtar Kelimeler: sarmal öğrenme, akran desteği, konuşma, yüksek sesle okuma, öğrenme

\section{French Abstract}

L'Efficacité de Multimédia Immersive Apprenant avec Support de Pair sur anglais Parlant et Lisant à haute voix

Cette étude a examiné les impacts du multimédia immersive apprenant la stratégie avec le pair le support sur des compétences de production dans la lecture et la conversation. Aussi examiné étaient les effets sur la performance par l'accomplissement d'étudiant. Le design quasiexpérimental avec le post-test a été employé pour l'étude. 80 étudiants universitaires de première année se sont inscrits dans le cours d'anglais langue étrangère ont été choisi pour cette étude. Les données ont été analysées utilisant ANOVA à sens unique. Les conclusions ont montré que le multimédia immersive apprenant avec le groupe d'entraide de pair a rapporté la significativement meilleure performance dans toutes les mesures de production orale pour lire et parler. Les analyses par l'accomplissement ont montré que les hauts étudiants d'accomplissement dans le multimédia immersive apprenant avec le groupe d'entraide de pair ont rapporté la significativement meilleure performance dans toutes les mesures de production orale seulement pour parler tandis que les étudiants d'accomplissement bas dans le multimédia immersive apprenant avec le pair ont soutenu le groupe rapporté la significativement meilleure performance dans toutes les mesures de production orale pour lire et parler. Ces conclusions ont montré que la technique multimédia immersive avec le support de pair a réduit l'utilisation de stratégies commutant le code parmi les étudiants et leur a permis de développer des compétences de production orales dans l'anglais s'approchant des modèles de locuteurs natifs particulièrement parmi des étudiants d'accomplissement bas.

Mots Clés: immersive apprentissage, pair, support, conversation, lisante à haute voix 


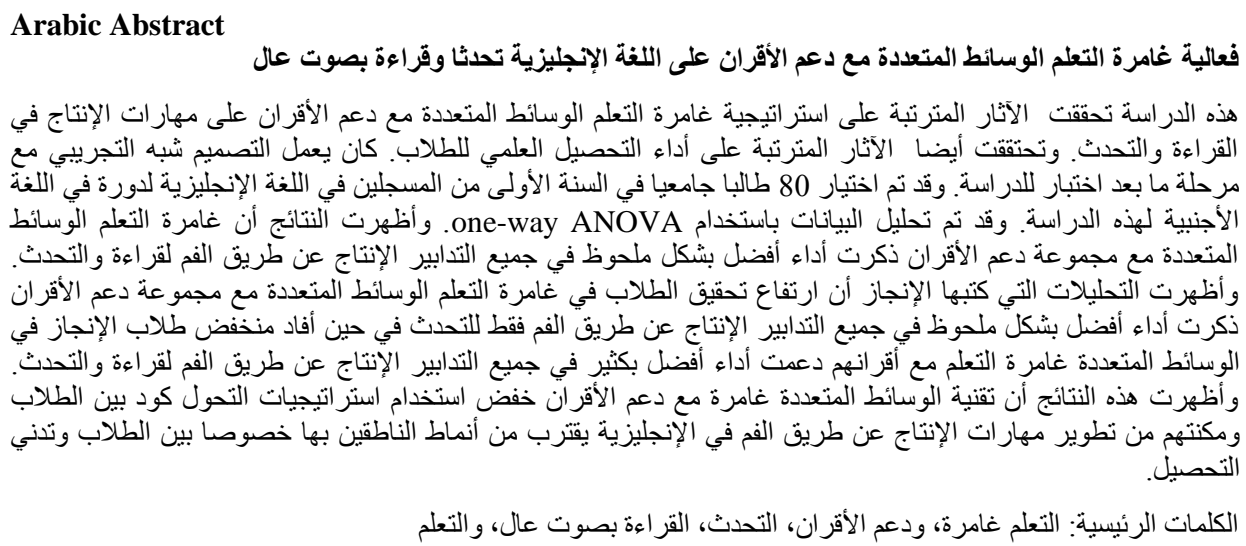

\title{
German Abstract \\ Die Wirksamkeit von immersiven Multimedia-Learning mit Peer-Unterstützung auf Englisch Sprechen und Lesen Laut
}

Diese Studie untersuchte die Auswirkungen der immersiven Multimedia-Lernstrategie mit PeerUnterstützung auf Produktion Fähigkeiten beim Lesen und Sprechen. Ebenfalls untersucht wurden die Auswirkungen auf die Leistung durch die Schülerleistung. Das quasi-experimentelle Design mit dem Post-Test wurde für die Studie verwendet. Für diese Studie wurden 80 Erstjahresstudierende ausgewählt, die in Englisch als Fremdsprachenkurs eingeschrieben waren. Die Daten wurden mit einer Einweg-ANOVA analysiert. Die Ergebnisse zeigten, dass das immersive Multimedia-Lernen mit Peer-Support-Gruppe berichtet, deutlich bessere Leistung in allen Maßnahmen der oralen Produktion für das Lesen und Sprechen. Analysen durch Leistung zeigten, dass die Hochleistungsstudenten im immersiven Multimedia - Lernen mit Peer - Support - Gruppe eine signifikant bessere Leistung bei allen Maßnahmen der oralen Produktion nur zum Sprechen erzielten, während die Schüler mit niedrigem Leistungsniveau im immersiven Multimedia - Lernen mit Peer - unterstützter Gruppe eine deutlich bessere Leistung erzielten Alle Maßnahmen der mündlichen Produktion für das Lesen und Sprechen. Diese Ergebnisse zeigten, dass die immersive Multimedia-Technik mit Peer-Unterstützung reduziert die Verwendung von Code-Switching-Strategien unter den Studenten und ermöglichte ihnen die Entwicklung von mündlichen Fertigkeiten in englischer Sprache, die sich mit dem Muster der Muttersprachler vor allem bei Studenten mit niedrigem Leistungsniveau.

Schlüsselwörter: immersives lernen, peer support, sprechen, vorlesen, lernen

\author{
Malaysian Abstract \\ Keberkesanan Pembelajaran Multimedia Mendalam dengan Sokongan Rakan Sebaya dalam \\ Pertuturan dan Pembacaan Bahasa Inggeris Secara Kuat
}

Kajian ini menyiasat kesan strategi pembelajaran multimedia yang mengasyikkan dengan sokongan rakan sebaya kepada kemahiran membaca dan bertutur. Juga disiasat kesan ke atas prestasi pencapaian pelajar. Reka bentuk kuasi-eksperimen dengan ujian pasca telah digunakan untuk kajian ini. 80 pelajar universiti tahun pertama mendaftar dalam bahasa Inggeris sebagai 
kursus bahasa asing telah dipilih untuk kajian ini. Data dianalisis dengan menggunakan ANOVA sehala. Dapatan kajian menunjukkan bahawa pembelajaran multimedia mendalam dengan kumpulan sokongan rakan sebaya melaporkan prestasi jauh lebih baik dalam semua langkahlangkah kemahiran untuk membaca dan bertutur. Analisis pencapaian menunjukkan pelajar memperoleh pencapaian tinggi dalam pembelajaran multimedia mendalam dengan kumpulan sokongan rakan sebaya melaporkan prestasi jauh lebih baik dalam semua langkah-langkah pengeluaran lisan hanya untuk bercakap manakala pelajar pencapaian rendah dalam pembelajaran multimedia mendalam dengan rakan sebaya disokong melaporkan prestasi jauh lebih baik dalam semua langkah-langkah kemahiran lisan untuk membaca dan bertutur. Penemuan ini menunjukkan bahawa teknik multimedia yang mengasyikkan dengan sokongan rakan sebaya mengurangkan penggunaan strategi beralih kod dalam kalangan pelajar dan membolehkan mereka untuk membangunkan kemahiran lisan dalam bahasa Inggeris menghampiri corak penutur asli khususnya dalam kalangan pelajar pencapaian rendah.

Kata Kunci: pembelajaran mendalam, sokongan rakan sebaya, bertutur, membaca dengan kuat, pembelajaran

\section{Russian Abstract \\ Влияние Иммерсивного Мультимедийного Обучения в Чтении Вслух и в Бесете с Коллегами при Изучении Англиского}

Это исследование изучало воздействий захватывающей мультимедийной стратегия обучения с поддержкой сверстников на производственных навыков чтения и устной речи. Более того, последствий его на производительность были исследованы достижения студента. Квазиэкспериментальной дизайн с послетестовом был занятых для исследования. 80 студентов первого курса вузов, обучающихся на английском языке в качестве иностранного языка курса были отобраны для данного исследования. Данные были проанализированы с использованием один из способов ANOVA. Находки показали, что иммерсивные мультимедиа обучения с группой поддержки сверстников сообщили о значительно более высокую производительность во всех меры из устного производстве для чтения и речи. Анализы полученный от достижения показали что высокие студенты достижений в иммерсивные мультимедиа обучения с группой поддержки сверстников сообщили о значительно более высокую производительность во всех мероприятиях устного производства только выступая в то время как низкие студенты достижения в иммерсивных мультимедийного обучения с экспертными при поддержке группы сообщили о значительно более высокую производительность из меры устного производства для чтения и речи. Эти находки показали что техника иммерсивная мультимедиа с сверстников поддержкой сократили использование стратегий кода переключения среди студентов и позволяет им развивать устные навыки производства на английском языке приближается образцы носителей языка особенно среди студентов низких достижений.

Ключевые Слова: иммерсивное обучение, поддержка со стороны коллег, говоря, чтение вслух, обучение 